\title{
EFFECT OF MODERN TEACHING METHODS AND NEW EDUCATIONAL TECHNOLOGIES ON THE CREATION OF EDUCATIONAL MATERIALS AND THE FORMATION OF TEACHING AND EDUCATIONAL COMPLEXES "KINDERGARTEN - PRIMARY SCHOOL"
}

\section{WPEYW NOWOCZESNYCH METOD NAUCZANIA I NOWYCH TECHNOLOGII EDUKACYJNYCH NA TWORZENIE MATERIAKÓW EDUKACYJNYCH I TWORZENIE KOMPLEKSÓW NAUCZANIA I EDUKACJI "PRZEDSZKOLE - SZKOKA PODSTAWOWA"}

DOI: $10.30540 /$ sae-2020-006

\begin{abstract}
A bstract
On the basis of use of modern research methods, the requirements for designing new types of teaching and educational complexes "Kindergarten - Primary School" were determined. It was established that the form and methods of kindergarten education have a certain analogy with the education in the first grades of primary school, which is one of the factors of feasibility of blocking and cooperation of the senior kindergarten groups with the elementary grades of general education schools and the formation of teaching and educational complexes on this basis, which enables receptiveness to demographic fluctuations and, if necessary, change of the function of kindergarten to the function of primary school, and vice versa - the flexibility and multivariance of the teaching environment is one of main conceptual provisions in building of network and typology of educational facilities at the present stage, on the basis of which the structural elements of school network in massive restrained urban development are formed.
\end{abstract}

Keywords: teaching and educational complex, kindergarten, primary school, group center, premises of educational section, cooperation

\section{Streszczen ie}

Na podstawie zastosowania nowoczesnych metod badawczych określono wymagania dotyczace projektowania nowych typów kompleksów dydaktycznych i edukacyjnych „Przedszkole - szkoła podstawowa”. Ustalono, że forma i metody edukacji przedszkolnej maja pewna analogię z edukacja w pierwszych klasach szkoły podstawowej, co jest jednym $z$ czynników umożliwiajacym blokowanie $i$ wspótpracę starszych grup przedszkolnych z pierwszymi klasami szkól podstawowych i tworzenie na tej podstawie kompleksów dydaktycznych i edukacyjnych, i może stanowić odpowiedź na zmiany demograficzne oraz $w$ razie potrzeby, zmiane funkcji przedszkola na funkcję szkoły podstawowej $i$ odwrotnie elastyczność $i$ wielowariantowość środowiska nauczania jest jeden z głównych pojęć koncepcyjnych w budowaniu sieci i typologii placówek oświatowych na obecnym etapie, na podstawie którego powstaja elementy strukturalne sieci szkolnej w masowym rozwoju urbanistycznym.

Słowa kluczowe: kompleks dydaktyczno-edukacyjny, przedszkole, szkoła podstawowa, centrum grupowe, siedziba sekcji edukacyjnej, współpraca 
Primary objectives of elementary school are the promotion of child's personality development, cultivation of desire and ability to learn in him/her and self-actualization. Vulnerability, curiosity and thirst for knowledge are typical for preschool and junior school children. At the same time, the younger schoolchildren get tired quickly; they need daytime sleep, reduction of lesson period, increase of breaks between lessons, alteration of classes, wide use of game elements during the educational process [1, 3]. It is recommended that the educational units for children have to be brought closer to nature and to create green recreational areas for them. Duration of primary education is 4 years.

The education of children in the primary segment of school education is traditionally conducted according to the class-lesson system. The premises of this age group include classrooms, rooms for the organization of extended school day, rest, recreation rooms, dressing rooms, toilet rooms. The relatively new and understudied issues in creation of material environment for primary grades include, first of all, the requirements for organization of teaching section for six-year-old children - first-grade students. For the education of young schoolchildren, it is recommended to preserve to a certain extent the kindergarten environment (which is habitual for them) by using predominantly game-based teaching methods and reduced lesson period - to 35 minutes, which will facilitate a consistent transition from the habitual regime of a child's organism [5].

In the class for six-year-old children, besides the desks, the special play space and nature study corners must be present. An important condition for teaching and education of children is their physical training, aesthetic education, music, rhythmic, drawing lessons. For these purposes, it is necessary to create, respectively, schoolwide rooms and special teaching and educational areas that take into account the psychophysiological peculiarities of children of this age.

An important hygienic requirement for the organization of educational and material environment for six-year-old schoolchildren is the provision of daytime sleep. According to sanitary requirements, sleep should last for 1.5-2 hours in a separate wellventilated room [9] (Table 1).

As evidenced by the analysis below, the additional conditions for education, teaching and recreation are created for children of this age group in accordance with their age characteristics. In practice, teaching classes for six-year-old children are often created at kindergartens located near the school buildings. In terms of functional structure, the sections for children are similar to pre-school institutions.

The premises for second and fourth grades should also be solved universally, by providing various forms of classes during the lesson process.

A compulsory requirement for junior grade sections is the availability of spacious student lounges for organization of a proper rest, during breaks, the recreational areas should provide active games, physical exercising. In such recreations, besides the rest, the schoolwide cultural mass events, rhythmic lessons, gymnastic classes can be held during breaks. The group for junior high school students also includes a singing and music classroom, a choreography studio, a handicraft room, a multifunctional room for extended school day organization.

Medical observations indicate various healthimproving aspects of swimming process effect on the organism of schoolchildren. Meanwhile, the level of provision of the school network with swimming pools is significantly lower than in the actual requirements [6].

An important area of school environment improvement is the organic combination of general education with artistic education - improvement of aesthetic education, development of the sense of beauty in children and adolescents, ability to understand and appreciate works of art and architecture.

A new group of premises appears in schools - the club activity rooms. Today, classrooms and laboratories, as before, are widely used not only for lessons but also for the organization of extended school days. In addition to these rooms, there are special club activity rooms: for young naturalists, painting and graphic, sculpture, choreography studios. These premises will further develop in the structure of school buildings. The specific list of club activity premises should be determined in accordance with the local traditions, the folk crafts nature and the level of development of network of children's out-of-school educational facilities.

Studies show that, in modern schools, library becomes the informational and technical center of educational institutions [5]. It is often located in the center of a school building and connects to the surrounding premises through sliding partitions, which allows the lectures to be held simultaneously with several classroom groups. The service premises are also being modernized: dining room, administrative and economic services, medical offices. According to the current regulations, the size of dining halls should provide meals for students in two seats. 
Table 1. Characteristics of teaching and educational complex for primary schoolchildren

\begin{tabular}{|c|l|l|l|}
\hline 1. & Daytime sleep & Sleep should last for $1.5-2$ hours in a separate well-ventilated room \\
\hline 2. & Reduction of lesson period & Reduction of lesson period - to $35 \mathrm{~min}$ \\
\hline 3. & Shift increase & Shift period is $10-30 \mathrm{~min}$ & It is recommended to bring the children educational area closer to nature \\
\hline 4. & Proximity to nature & Game elements are widely used during the lessons \\
\hline 5. & Game elements & a &
\end{tabular}

Table 2. Social and pedagogical regulations for kindergarten group center premises and primary school educational sections premises

\begin{tabular}{|c|c|c|c|c|}
\hline \multicolumn{5}{|c|}{ List and Areas of Kindergarten (KG) Group Center Premises } \\
\hline No. & Name of premises & Measurement unit & \multicolumn{2}{|c|}{ Pre-school groups } \\
\hline 1. & Dressing room & sq.m. per one place & \multicolumn{2}{|c|}{0.9} \\
\hline 2. & Game room & sq.m. per one place & \multicolumn{2}{|c|}{3.0} \\
\hline 3. & Bedroom & sq.m. per one place & \multicolumn{2}{|c|}{3.0} \\
\hline 4. & Toilet room & sq.m. per one place & \multicolumn{2}{|c|}{1.0} \\
\hline 5. & Dining room & sq.m. & & \\
\hline \multicolumn{5}{|c|}{ List and Areas of Educational Sections for 1st Grades (PS) } \\
\hline \multirow{2}{*}{ No. } & \multirow{2}{*}{ Name of premises } & \multirow{2}{*}{ Measurement unit } & \multicolumn{2}{|c|}{ Educational section for 1 st grades for $25-30$ students (not less) } \\
\hline & & & for 25 students & for 30 students \\
\hline 1. & Game room & sq.m. per one place & 2.4 & 2.0 \\
\hline 2. & Bedroom & sq.m. per one place & 2.4 & 2.0 \\
\hline 3. & Toilet rooms & sq.m. per one place & 1.0 & 1.0 \\
\hline 4. & Recreational room & sq.m. per one place & 2.0 & 2.0 \\
\hline 5. & Wardrobe & sq.m. per one place & 0.2 & 0.2 \\
\hline 6. & Teacher's room & sq.m. & 16 & 18 \\
\hline \multicolumn{5}{|c|}{ List and Areas of Educational Sections for 2nd - 4th Grades (PS) } \\
\hline \multirow{2}{*}{ No. } & \multirow{2}{*}{ Name of premises } & \multirow{2}{*}{ Measurement unit } & \multicolumn{2}{|c|}{ Educational section for 1 st grades for $25-30$ students (not less) } \\
\hline & & & for 25 students & for 30 students \\
\hline 1. & Classrooms & sq.m. per one place & 2.4 & 2.0 \\
\hline 2. & Foreign language room & sq.m. per one place & 2.4 & 2.0 \\
\hline 3. & Multifunctional room for extended school day groups & sq.m. per one place & 2.4 & 2.0 \\
\hline 4. & Handicraft workshop & sq.m. per one place & 3.6 & 3.6 \\
\hline 5. & Toilet rooms & sq.m. per one place & 0.2 & 0.2 \\
\hline 6. & Recreational room & sq.m. per one place & 2.0 & 2.0 \\
\hline 7. & Wardrobe & sq.m. per one place & 0.2 & 0.2 \\
\hline 8. & Teacher's room & sq.m. & 16 & 18 \\
\hline
\end{tabular}


The administrative and economic premises are supplemented by a room of teacher's psychological management, a curriculum office and other services.

Thus, as the above analysis shows, the new forms and methods of teaching cause a significant expansion of composition and increase of kindergarten and primary school premises areas (Table 2).

One of the important requirements for the educational and material environment is the creation of conditions for the physical development of a child. Child's body differs from adult's body in that child is in a state of continuous growth and development. Child's body responds to various external factors. At this age, there is the change of the body as a whole. It is to such "hinge" periods that the transition of children from kindergarten to primary school belongs. Therefore, the cooperation of kindergarten and primary school and their combination into an educational and teaching complex contribute to the education of healthy children and, in general, an intact generation.

During the examination of students, the vision disorders and disorders of other body systems are often found. These disorders are most often found in pre-school and primary school-age children. One of the main tasks of education is the proper physical development of a child, which provides the optimal mechanical load on the musculo-skeletal system of growing child's organism. Therefore, it is important to control child's life activity continuously.

Pre-school-age and school-age children have high mobility, but numerous data of studies of dynamic regime for pre-school children and young schoolchildren confirm that children's physical activity decreases when they enter kindergarten and primary school. Restrained physical mobility adversely affects child's growth and mental development. For this reason, neither low physical mobility nor the exercising of sports or works that may adversely affect child's development should be allowed [9].

Properly organized day regime creates cheerful mood, interest in educational and creative activities, games and promotes the normal development of a child.

An important issue of teaching and education of children in a teaching and educational complex is the ensurance of an optimal balance between mental and physical activity in accordance with the anatomical and physiological, psychological characteristics of a child [9].
The hygiene of educational work in the preparatory classes is constantly linked to the students' day regime (Table 3).

Table 3. Approximate organization of the regime for kindergartens and primary school students

\begin{tabular}{|r|l|c|}
\hline No. & \multicolumn{1}{|c|}{ Regime elements } & Timing \\
\hline 1. & First class & $35 \mathrm{~min}$ \\
\hline 2. & First break & $10 \mathrm{~min}$ \\
\hline 3. & Second class & $35 \mathrm{~min}$ \\
\hline 4. & Second break (breakfast) & $20 \mathrm{~min}$ \\
\hline 5. & Third class & $35 \mathrm{~min}$ \\
\hline 6. & Dynamic break (walk) & $55 \mathrm{~min}$ \\
\hline 7. & Third break & $10 \mathrm{~min}$ \\
\hline 8. & Fourth class & $35 \mathrm{~min}$ \\
\hline 9. & Walk & $1 \mathrm{~h}$ \\
\hline 10. & Dinner & $30 \mathrm{~min}$ \\
\hline 11. & Sleep & $2 \mathrm{~h}$ \\
\hline 12. & Supper (snack) & $20 \mathrm{~min}$ \\
\hline
\end{tabular}

The second important aspect of the day regime is sleep sufficiency, during which all major metabolic and cellular alterations that determine the formation of child's skeleton take place. The best thing for sleep is the fresh air. It affects the skin, the mucous nose membranes and the upper respiratory tract, causing rapid sleep onset. Sleeping on the open air can replace walking, especially at cold and transitional seasons [9].

At the day regime, 12-12.5 hours of sleep go to junior (3-4 years) and middle (4-5 years) kindergarten groups, 2 hours of which are for a single daytime sleep. For children of senior (5-6 years) and preparatory (6-7 years) groups, 11.5 hours (10 hours at night and 1.5 at day) go to sleep.

A large number of students experience the lack of sleep. It is associated with the early start of classes of the first shift (at 8:30 am and even at 8:00 am) and, correspondingly, the early rising of children, as well as the late bedtime. Late falling asleep is caused by lasting preparation of homework and lasting watching of TV shows and video films. Lack of sleep has a negative effect on the higher nervous activity of children. With lack of sleep, there are mood swings and significantly reduced performance. However, if the correct sleep pattern is set, these disorders tend to disappear.

The day regime in the senior kindergarten groups and first grades of primary school consists of four 
lessons daily, three meals, and daytime sleep for $1.5-2$ hours. It is very important for children to stay outdoors for 1.5-2 hours. Games and outdoor walks are of particular importance. Open air has a beneficial effect on organism: it activates metabolic processes and has a positive effect on growth and development. Depending on the climatic conditions, the seasons, children have to spend maximum time outdoors. Under any conditions, the daytime walks must take place in the morning and afternoon; the total length of children's staying outdoors should not be less than 4 hours [9].

At pre-school age, the formation of circadian periodicity takes place in the organism activity. The education tasks are significantly larger during this period. Children get accustomed to perform simple duties, simplest working activity, greater self-care. In the middle and senior groups, a lot of work should be done in children's preparation for learning.

The kindergarten day regime must be differentiated according to groups. The junior group consists of 3-4 year-old children, the middle group - of 4-5 yearold children, and the senior group - of 5-6 year-old children.

Kindergarten education and teaching programs provide for the organization of classes according to the morphofunctional characteristics of children:

- for the junior group - 10 classes per week for 10-15 minutes;

- for the middle group - 10 classes per week for 20 minutes;

- for the senior group - 15 classes per week for 20-25 minutes.

The break duration between classes is 10-12 minutes, during which it is advisable to organize mobile games of moderate intensity. In comparison with the senior groups, little children are given more time to have a meal, to cultivate the cultural and hygiene skills that the children begin to master. Staying in the open air during winter should last not less than 3-4 hours, and during summer - all day long [9].

In the regime for middle-group children, the duration of organized classes increases and their nature is somewhat complicated. With senior-group children, 2-3 classes are held daily. All spare time before breakfast, during walks and especially in the afternoon after daytime sleep - is reserved for games, that is, activities typical for the psychophysiological nature of pre-school child. In this regard, the kindergarten education process is based on children's play activities. For the preparatory group, the compulsory classes are prolonged and complicated.

For the play activities, the time is given in the morning (before breakfast), during the walks in the morning and afternoon, after the daytime sleep and the evening before bedtime. Children's games are diverse in nature and content: peaceful and active, individual and team, everyday and didactic. They help children to perceive the world more deeply, help to form logical thinking, arbitrary attention. Active games affect the development of physical skills, promote the cultivation of activity, ingenuity, courage.

Studies have clearly shown that for six-year children, 45-minutes classes are extremely fatigable, so it is recommended that the classes for first grades of primary school should last 35 minutes, which will facilitate a consistent transition from the usual child's kindergarten routine where the lessons last 30 minutes. It is also advisable to take a physical break every 15-20 minutes so that the children can do some exercises.

In order to organize a proper rest during the breaks, the recreational areas should provide active games, physical exercises.

In developing the regime for students, the peculiarities of nervous system functioning are considered: the high level of the cerebral cortex activity during morning and daytime hours, its decrease after dinner and drop in the evening. The working ability of students during the day has two lifts that coincide in time with periods of high levels of physiological functions: from 8:00 am to 12:00 am and from $16: 00 \mathrm{pm}$ to $18: 00 \mathrm{pm}$. In this case, as a rule, the first rise in working capability is higher and longer than the second one.

Outdoor activities are a powerful wellness factor. Children should spend the time outdoors before and after homework preparation. The total length of staying outdoors must be: for junior school age - not less than 3-3.5 hours, for middle age $-2.5-3$, and for senior age $-2-2.5$ hours. In modern conditions, this day regime element is most often violated due to students' teaching overload: the outdoor time and the physical activity of children are reduced.

Great attention must be paid to the students' visual work conditions. Classroom luminance must be at least 1:5 when orienting toward the southeast side of the horizon. The natural illumination ratio at the distance from window to desks must be $1.5 \%$.

Workplaces for students should provide that the text on the classroom board from the most distant places 


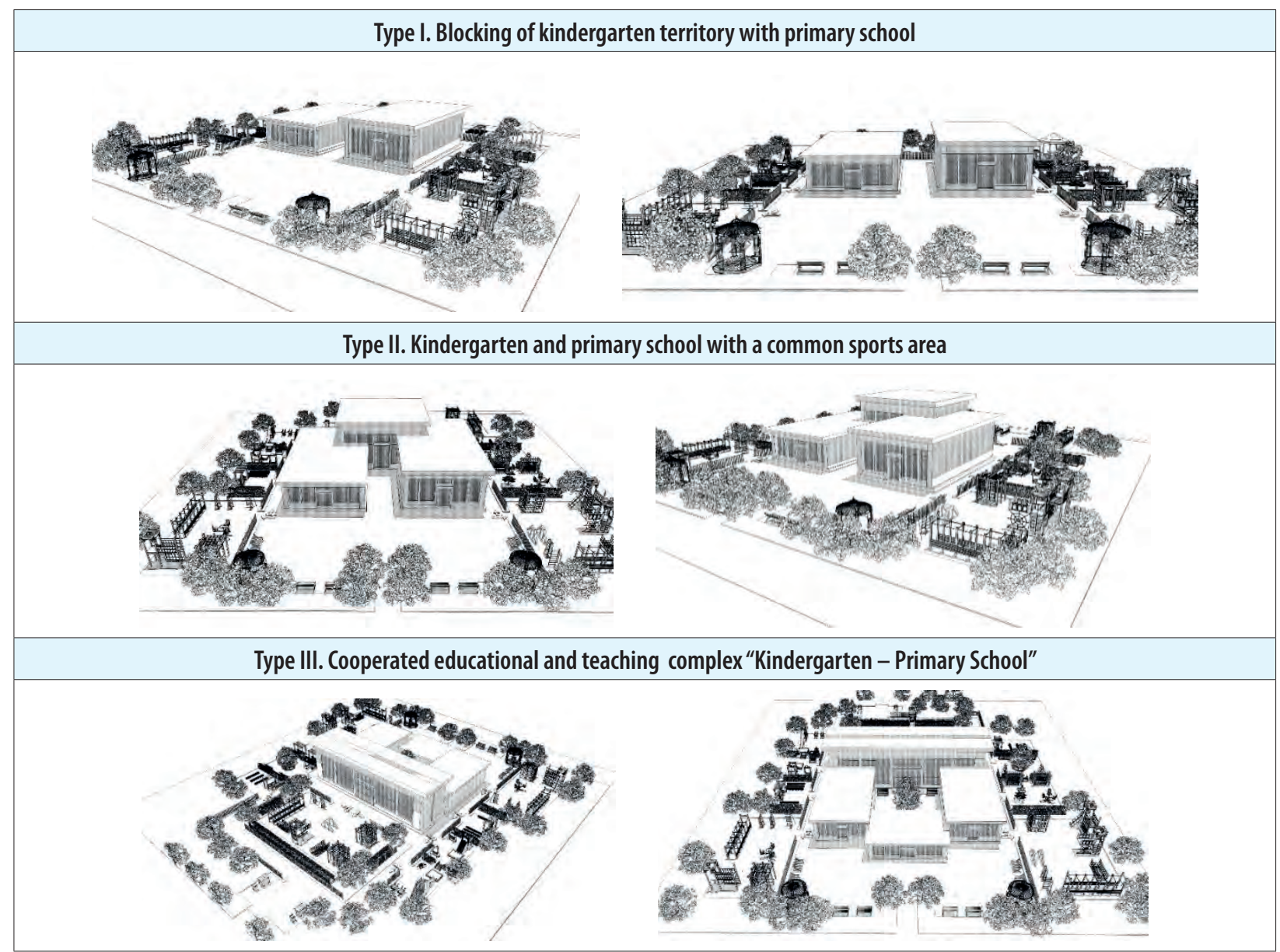

Fig. 1. Methods of formation of educational and teaching complex territory

is normally visible. Therefore, when organizing the educational environment and the placement of classroom tables, it is necessary to ensure the optimal sight angle of the students, which must be more than $30^{\circ}$.

The form and methods of education in kindergarten have a certain analogy with the education in the first grades of primary school, which is one of the factors of feasibility of blocking and cooperation of kindergarten senior groups and first grades of general education schools and formation of educational complexes on this basis (see Fig. 1).

In addition to the pedagogical advantages, the creation of such complexes enables receptiveness to demographic fluctuations and, if necessary, change of the function of kindergarten to the function of primary school and vice versa. Flexibility and multivariance of the teaching environment is one of main conceptual provisions in building of network and typology of educational facilities at the present stage.

The school unit provides the appropriate level of general education for students in accordance with the requirements of the State Standard of General Secondary Education. The school unit can include classes with advanced study of certain subjects, extended school day groups, school residential institution for students living in remote areas, etc.

All this confirms the feasibility of blocking and cooperation of primary schools and kindergartens.

\section{REFERENCES}

[1] Age possibilities of knowledge acquisition - junior school classes /Ed. Elkonika D.B., Davydova V.V. - M., 1966.75 p.

[2] Architecture of Schools: The New Learning Environments. Mark Dudek. Architectural Press. /ISBN 0750635851, 9780750635851/.2000. $-238 \mathrm{p}$.

[3] Havrilychev H. Game teaches and educates //Primary school. 1977. No. 4.

[4] Haiduchenia A.A.: Dynamic architecture. K.: Budivelnyk, 1983.

[5] Hrechkovskaia I.A.: Planning and organization of the spatial environment of subject rooms and workshops of general education schools (based on the use of active teaching methods) // Trends in the development of typology and design of teaching and educational buildings. / CNIIEP of educational buildings. M., 1985. 38-54 p. 
[6] Kovalskii L.N.: Development problems of architecture of educational and teaching buildings: thesis for a Candidate Degree in Architecture: spec. 18.00.02 "Architecture of buildings and structures" / L.N. Kovalskii. - K., 1996. 339 p.

[7] Modern schools of thought // Architect Journal. - 1986. Vol. 184, №39.

[8] Nias J. Southworth G. Compber P.: Whote School Curriculum Development in the Primary School. - London. Washington, D.C., 1992.

[9] Shpakovska V.T.: Architectural organization of environment for students of preparatory classes of general education schools: thesis for a Candidate Degree in Architecture: spec. 18.00.02 "Architecture of Buildings and Structures" / V.T. Shpakovskaia - K., 1983. 203 p.

[10] Whote School Curriculum Development in the Primary School. Jennifer Nias, Geoff Southworth, Penelope Compber. - London. Washington, D.C., 1992. 257p.

[11] Yurchyshyn O.M.: Objects of pre-school and out-of-school education of low capacity in a residential environment: abstract of a thesis for a Candidate Degree in Architecture: spec. 18.00.02. "Architecture of buildings and structures" / O.M. Yurchyshyn. - L., 2009. 21 p.

\section{Acknowledgments:}

The work was financed by the Kiev National University of Building and Architecture

\section{Podziękowania:}

Praca była finansowana przez Kijowski Narodowy Uniwersytet Budownictwa i Architektury 